\title{
I IS FOR AGENCY: EDUCATION, SOCIAL JUSTICE, AND AUTO/BIOGRAPHICAL PRACTICES'
}

RICIA ANNE CHANSKY

University of Puerto Rico at Mayagüez

EDWARD G. CONTRERAS SANTIAGO

University of Puerto Rico at Mayagüez

FERNANDO E. E. CORREA GONZÁLEZ

University of Puerto Rico at Mayagüez

MARCI DENESIUK

University of Puerto Rico at Mayagüez

JOCELYN GÉLIGA VARGAS

University of Puerto Rico at Mayagüez

\section{CATHERINE M. MAZAK}

University of Puerto Rico at Mayagüez

ABSTRACT In this polyphonic pedagogical essay, six members of the Department of English at the University of Puerto Rico at Mayagüez discuss their incorporation of auto/biographical acts into course syllabi for the purpose of facilitating social justice in and through education. Drawing from disciplinarily diverse faculty members holding different contractual positions within the university, this essay demonstrates the widespread need for creating space for student voices as means of supporting agency on- and off-campus, especially in times of disaster, tragedy, and crisis.

Keywords: Autobiography. Pedagogy. Teaching. Social justice. Puerto Rico. Disaster.

RESUMO SOU DE AGÊNCIA: EDUCAÇÃO, JUSTIÇA SOCIAL E PRÁTICAS AUTO/BIOGRÁFICAS

Neste ensaio pedagógico polifônico, seis membros do Departamento

1 In this multivoiced essay, Ricia Anne Chansky crafts an introduction that situates six members of her department in conversation with each other regarding the benefits of auto/biographical pedagogies as a means of situating student agency and teaching for social justice: Edward G. Contreras Santiago discusses service learning, Fernando E. E, Correa González considers general education courses, Marci Denesiuk focuses on creative writing, Chansky analyzes literature courses, Catherine M. Mazak considers linguistics, and Jocelyn Géliga Vargas reflects on assessment. 
de Inglês da Universidade de Porto Rico, em Mayagüez, discutem sua incorporação de atos autobiográficos nos programas de curso, com o objetivo de facilitar a justiça social na educação e através dela. A partir de membros do corpo docente disciplinarmente diversificados, com diferentes posições contratuais dentro da universidade, este ensaio demonstra a necessidade generalizada de se criar um espaço para as vozes dos estudantes, como meio de apoiar a agência dentro e fora do campus, especialmente em tempos de desastres, tragédias e crises.

Palavras-chave: Autobiografia. Pedagogia. Ensino. Justiça social. Porto Rico. Desastre.

\section{RESUMEN SOY DE AGENCIA: EDUCACIÓN, JUSTICIA SOCIAL Y PRÁCTICAS AUTO / BIOGRÁFICAS}

En este ensayo polifónico pedagógico, seis miembros del Departamento de Inglés de la Universidad de Puerto Rico en Mayagüez discuten su incorporación de actos autobiográficos en los programas de los cursos con el propósito de facilitar la justicia social en y mediante la educación. Este ensayo demuestra la necesidad generalizada de crear espacios para validar las voces de los estudiantes a fin de apoyar su agencia individual dentro y fuera de la universidad, especialmente en tiempos de desastres, tragedias y crisis.

Palabras claves: Autobiografia. Pedagogía. Enseñanza. Justicia social. Puerto Rico. Desastre.

\section{Introduction}

The following is a polyphonic discourse on the uses of auto/biographical pedagogies and educational practices currently employed by certain faculty members in the Department of English at the University of Puerto Rico at Mayagüez (UPRM). While by no means an exhaustive overview of all the work being done in our department with auto/biographical pedagogies, this discursive piece serves as an indication of the many disciplinary spaces within our department in which auto/biographical pedagogies are being practiced and provides a sense of the differing student and faculty demographics participating in auto/biographical assignments and practices, ranging from service learning projects to literary analysis to ed- ucational assessment. The genres of the auto/ biographical assignments, methodologies, and practices discussed in this essay are also varied, spanning oral history, poetry, creative nonfiction, and self-reflexive essays. It is our intent to interweave here these micro-narratives on auto/biographical pedagogies into a nuanced conversation on the ways that we both independently and as a collaborative body use life stories - in our respective educational spaces and with diverse participating subjects - to facilitate voice and agency in our department, on our campus, and in Puerto Rico. Furthermore, we see our efforts with auto/biographical acts and practices in our respective courses and other sites of educating, both on-and off-cam- 
pus, as a means of working for social justice through empowering students, colleagues, and the larger community to see the value of the self and the relationship between education and the situated subjectivities of the experiential I.

Our department may be thought of as an English Studies model, as defined by Bruce McComiskey in his US National Council of Teachers of English (NCTE) book, English Studies: An Introduction to the Discipline(s), in that it houses courses in literature, linguistics, English education, composition and rhetoric, creative writing, communications and media, film studies, and critical theory, among others. In addition to offering an undergraduate degree in English with concentrations in either literature or linguistics and a minor in writing and communications, the department supports an English education program that leads to teacher certification on the secondary-level and an undergraduate certificate in film studies; awards a Master's Degree in English education; and, serves the entire university through the teaching of undergraduate-level general education courses in introductory, intermediate, and advanced first-year English. Every undergraduate student matriculated in an undergraduate degree-granting program on our campus, independent of their declared major, must complete twelve credit hours (or the equivalent) in our department. While many of the mandatory first-year courses are language development based to some extent, they also function across the board as essential spaces for the growth of critical thinking, reading, writing, speaking, and listening skills.

Within our department, we have three main groups of teaching faculty: tenure track, full-time faculty; adjunct faculty who are primarily ABD or already hold terminal degrees; and, Graduate Teaching Assistants (GTAs) from our MA program who are instructors of record for the courses they teach. This essay includes contributions from faculty members who represent several of the disciplines of English present in our department as well as from those who hold each type of the aforementioned teaching contracts. The contributors were invited to participate in this essay based upon disciplinary diversity, an intent to illustrate the breadth of projects taking place within the department, and a desire to represent the three categories of contracted faculty teaching on our campus. These decisions were made, then, to convey that auto/ biographical pedagogies are being used in our department by a number of faculty members at multiple different stages in their teaching careers, with differing contractual obligations, in an array of courses that span several disciplines and enroll a wide variety of students - from those on the introductory-level to those majoring in English, and even at an administrative level.

Perhaps this specific cultural moment in Puerto Rico is to some extent the underlying cause for our widespread interest in life stories and the lives they chronicle. We are mired in an economic depression and have a US Congressionally-appointed Fiscal Oversight and Management Board overseeing both Puerto Rico and the university system as a result of the Puerto Rico Oversight, Management, and Economic Stability Act of 2016, PROMESA. This fiscal control board has imposed strict austerity measures in an attempt to exact repayment on debts. Both the debts themselves and the austerity measures are under scrutiny as the validity of these investments and the measures being taken to recoup their losses are questionable, to say the least. Within our troubled financial landscape, however, comes another devastating blow. On September 20, 2017, a category five hurricane struck the Puer- 
to Rican archipelago causing massive destruction. Governmental support and assistance for the millions of US citizens of Puerto Rico was not forthcoming in a timely manner resulting in widespread humanitarian concerns for the welfare of the people. In other words, we are currently living through the aftermath of a natural disaster hampered by a detrimentally underwhelming governmental response, situated within the midst of an ongoing fiscal crisis.

The first four pieces in this essay relate directly to this catastrophe, Hurricane María, and restarting the semester after our poststorm forced recess, a time in which many of us were deeply marked by the events we experienced and struggling through our own fraught existences while continuing to teach classes. In his contribution, Edward G. Contreras Santiago discusses a service learning project he developed with his students based upon their auto/biographical narratives that describe what they witnessed both during and after the hurricane. In his project, students ultimately improved their English-language abilities, academic writing, and critical skills through a writing assignment tied to their project organizing and delivering supplies to local communities in desperate need. His research suggests that service learning projects may contribute to the restoration of student agency in the wake of tragedy. The direct action of a service learning project and the ability to witness the results of one's actions, he indicates, may work towards undermining the sense of futility and/or helplessness resultant from a disaster.

Fernando E. E. Correa González likewise writes about his lesson designed to begin again the autumn semester in which his pedagogical project to create a literary anthology of students' post-hurricane life stories bridges back to his own creative work as a verse diarist. His reflections on this curricular unit suggest that the act of publishing or otherwise making public students' narratives in times of crisis is a key element to the restoration of agency. Correa González's previous experiences with self-publishing through digital means led to the anthology being sold on Amazon. com. This act of positioning student life stories on a popular web-business alongside works of more recognizable authors functions as a means to convey to the students that the lives in their stories are valuable. His work explores what this public (and monetary) recognition might signify to a first-year student who has just survived tragedy and is stalled in its aftermath while in the heart of a crippling economic depression. It raises the questions: What does it mean to be repositioned - through one's life narrative - from traumatized subject to published author? How might students' undermined agency be reclaimed through pedagogies that situate recognizing the self as essential to the learning process?

Shifting between the self and the other in a series of creative nonfiction exercises that lead students from the autobiographical to the biographical, Marci Denesiuk's assignments work to facilitate students' understanding of the self as a subject worthy of consideration and care while stimulating empathy for the other. In our post-hurricane landscape, her adaptation of linguist Samuel Hayakawa's "ladder of abstraction" becomes a way for students to delve into the details of their experiences with disaster, demonstrating that their words - and the experiences to which they are tied - are indeed meaningful and worth exploring. When students learn to value the details of their own experiences, she explains, they, in turn, are more able to engage with the lives of others. As one of the students enrolled in her course articulates, "we all have a story to tell." Denesiuk's auto/biographical unit - with emphasis placed equally on the life stories of the self and the other - demonstrates that when we 
are taught to value our own experiences and the narratives that emerge from them, we may be better positioned to hear and respect the stories of others.

My own contribution to this collection discusses using students' personal experiences with the hurricane as a means to theorize the Anglophone Caribbean literatures on my course syllabus of the same theme. In this contribution, I extrapolate upon the idea that - as Maria Conceiçao de Passeggi and others have introduced elsewhere and Contreras intimates in this essay ${ }^{2}-$ it is necessary to acknowledge the selfhood of the student in the classroom before learning can happen, especially in cases of the traumatized subject. In other words, we cannot teach successfully our students until we address the material and psychological concerns that impede their learning. This grouping of narratives, then, argues that auto/ biographical pedagogical practices present teachers with opportunities to recognize students as autonomous selves and, in turn, facilitate our abilities to help them see themselves in the same vein. By incorporating these techniques into our courses, we are then able to bridge back to our lessons more effectively after addressing specifically these apprehensions and meeting them openly with respect and care: understanding, of course, that this recognition cannot be a finite act.

Closing this essay are two contributions that demonstrate that - while the recent hurricane is, of course, in the forefront of our minds the ongoing economic depression and the politics that have shaped this crisis in Puerto Rico have also contributed to the ways in which our faculty employ auto/biographical narratives as educational practice and a means of promoting social justice. In her study of "literacy au-

2 See, for example, “Autobiographical Narratives: Pedagogical Practice as a Lifeline for Hospitalized Children" by Conceição de Passeggi et al. a/b: Auto/Biography Studies (32.2, Winter 2017). tobiographies" as a core element of her graduate-level course in literacy studies, Catherine M. Mazak discusses the elements that shape contemporary English-language learning in Puerto Rico, including: colonial practices, desire to participate in contemporary media, professional opportunities, potential social stigma, circular migration between Puerto Rico and the US, and complex representations of national identity/ies. Mazak clarifies that "[a]s Puerto Rican students develop into Puerto Rican English teachers, they walk a carefully navigated path between appropriation of English and accusations of Americanization." These literacy autobiographies, however, reveal that the majority of students approach second language learning outside of school for the purpose of engaging in diverse textual genres as personal interest and/or entertainment. Their life narratives, then, demonstrated to the graduate students - future teachers - that "[t]hey were finding English on their own terms and using it for their own purposes from a very young age" despite the colonial language policies under which they were operating.

While each member of this collaborative project has used their contribution to this essay to explore pedagogical projects within specific learning communities that utilize auto/ biographical narratives to promote student agency and, in turn, social justice, Jocelyn Géliga Vargas extends our discussion by exploring a project that looks towards the benefits of incorporating life narrative methodologies at an institutional-level. Her collaborative oral history project related to the UPRM Bridge Program, the Center for University Access, demonstrates that not all educational programs fit traditional paradigms for review and assessment. At a time in which administrators and government officials (on island and off) are attempting to cull academic programs that they do not register as essential, she positions oral history as 
an alternate means of assessment; one that serves to justify the human impact of educational programs and functions as a means to articulate the argument for the "democratization of higher education." According to Géliga Vargas "oral history emerges as a compelling strategy to document life stories and individual and collective struggles forged against the grain of exclusionary meta-narratives of Puerto Rico's current plight." Indeed, as all of the elements of this polyvocal essay maintain, in the fight for social justice in and through education, multiple forms of life narrative integrated into diverse educational contexts stand to resituate disempowered students (and educators) as subjects who are self-sanctioned to move from the margins to the center of their life stories.

It is important to note that while we are all, in different ways, reading forms of auto/ biographical narratives with our students, each of the lessons discussed in this essay are committed to the writing, otherwise crafting, or collecting of original auto/biographical narratives as important elements of our conceptualizations of auto/biography as a means of promoting social justice in and through educational practices. We see the act of producing auto/biographical narratives as essential to our commitment to fostering agency in our learning communities. Welcoming the self into the classroom or educational space - assuring students that we do see them as individual selves and that we recognize lived experiences as valuable additions to the work of our classes - begins to rehumanize subjects that have been dehumanized through systematic colonization and subjugation, denial of the rights and benefits of citizenship, and repeated attempts to remove basic human services from a population in a manner that has resulted in numerous humanitarian concerns well before Hurricane María shattered the island.

\section{Service Learning}

Image 1 - Loading the bus for Morovis.

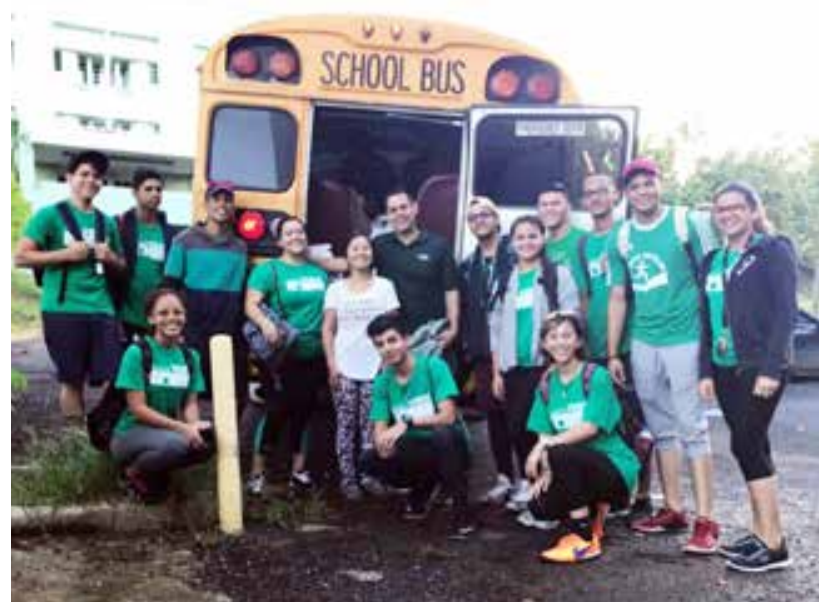

Source: Photo by Alexandra Jeannette.

It is no secret that service learning has a major presence in higher education, with some countries including it as a part of their mandatory curricula. Erasmus (2009) recognized service learning as an "effective vehicle for embedding community engagement activities in academic work" (46). This definition reflects beliefs of linking social responsibility and education with the hope of creating meaningful experiences that will develop and nurture student's understanding of the needs and realities of a global society. Members of our English department at UPRM have demonstrated their belief in supporting community and university driven projects, such as: El Meson Colegial, which provides snacks for students; the restoration of the municipal children's library, Biblioteca Juvenil Mayagüez; and, the university food drive Come Colegial, among others. Many of our faculty members and students are also involved with other grassroots movements, like "La Brigada Solidaria del Oeste." This brigade was founded after Hurricane María and is composed of faculty members, community leaders, and volunteers who work to provide access to food, water, or other services while ensuring that citizens impacted by the hurricane are helped and, most importantly, heard. 
The university resumed class after the hurricane on October 30 , even though the majority of the island was still without power or water. I teach sections of the introductory-level, general education course, Basic English, and at our first course coordination meeting post-María, faculty members took turns explaining their current status. Each colleague expressed suffering as they explained their situation at home and current mental state. I heard about the long lines to get gasoline and countless visits to supermarket to see if they had finally delivered ice. I felt embarrassed that I had regained running water and power quicker than roughly $98 \%$ of the island. Hearing my colleagues with their struggles and how they were helping their neighbors made me question my lack of contributions towards "levantando la isla."

At our first English department meeting after the storm, the directors handed out a survey that they created to understand our current state and needs post-hurricane. They encouraged us to share the same survey with our students so that we could understand and be empathetic with their situation. I administered the survey to the students enrolled in my classes and many indicated that they did not have electricity in their dorms. Even worse, some students expressed that they did not have enough to eat. How could I expect students to succeed - many of them in their first semester at the university - when they didn't even have enough food for their week? Based upon the troubling information that I learned, I offered to buy groceries for two students in particular, although only one accepted. At first, the response of the student who accepted was "profe, esas son tus habichuelas." ${ }^{4}$ I replied towards that comment, "a can of beans

3 "To lift the island" is a popular slogan adapted to represent the attitudes and spirit of Puerto Ricans in the aftermath of Hurricane Maria.

4 This expression is used when someone doesn't want to impose or take something because of it being someone else's earning. can feed a family." This comment let him know that regardless of him not being direct family, I viewed him like family and I was not going to let him starve. This exchange made me realize that the situation was very difficult for my students and those around the island. I asked my students what they thought about our crisis and they agreed that action was necessary and, more importantly, they acted.

In the following class, my students and I began to discuss the current state of Puerto Rico and how dubious we were of the big organizations collecting donations. Social media posts and news outlets were constantly debating and evaluating how funds were being misused and my students indicated that more needed to be done to help Puerto Rico. After several discussions, the students and I decided that we wanted to deliver supplies to families all over the island as part of the course. I warned them that their idea demanded a serious commitment and that a lot of work needed to be done in order to do this project properly, but they showed no hesitation.

In the next class, we decided that we would think of the supplies that we wanted to deliver and the communities that most needed our help. Students highlighted their own experiences with food supplies delivered from the US Federal Emergency Management Agency (FEMA $)^{5}$ and other nonprofits and created a list of what should be collected. Although grateful for what they had received, students indicated that the food brought to them from these entities was not something they were accustomed to eating and they missed their traditional aroz y habicheulas. Although our main focus was food, we knew that other items like diapers, batteries, towels, and personal hygiene products would also help greatly. The students' firsthand understanding of civic needs

5 FEMA is a United States organization that helps with disaster relief. 
and a willingness to work for the betterment of their own neighborhoods, helped design the approach towards this service learning assignment, making the design a collaborative, ground up project.

The communities were not chosen randomly. Students first discussed what was happening in their own barrios or where they heard that help was needed, and they chose where the class as a whole should go. As they talked through what areas had the most need and where they could do the most good, spirit and comradery in the class grew. Students were excited to form part of the initiative. Moreover, they started to express themselves and refer to the project in English. This leadership initiative speaks to Alexander Astin et al.'s notion of empowerment through service learning, in which the authors state, "an important 'leadership development' challenge for higher education is to empower students, by helping them develop those special talents and attitudes that will enable them to become effective social change agents" (2). It appears as though students' regained sense of being active agents in their communities and lives, developed through the service learning project, impacted their level of confidence communicating in a second language.

Members of the course eventually went to three towns in just over the span of one week: Utuado, Añasco, and Morovis. We went to Utuado and Morovis because these two pueblos were still reporting $0 \%$ electricity almost two months after the hurricane. Our trips to these towns took place on Sundays, with the exception of one trip that was made on Thanksgiving. It took roughly two hours of driving each way to reach each of these two designations. The Thanksgiving visit was made to Añasco, which is ten minutes away from the university. That excursion focused on giving meals to two elderly homes and neighboring communities that still had no power. The Thanksgiving trip was specifically designed to give an opportunity for participation to those students who lived close to the university and others that were busy with jobs or their families a chance to participate. Students taking part in the service learning project also had the option of going on the expeditions to deliver supplies or working in the office to organize the provisions in shifts of no less than two hours at a time.

We decided that we would prepare a grocery bag and a hygiene pack for each family. In less than two months we managed to gather over 600 bags filled with the following products: rice, beans, salchichas, Chef Boyardee products, canned tuna, and nutritional bars. The hygiene packs included: toothpaste, toothbrush, a bar of soap, and sanitary pads. We placed all of these in one recyclable bag and handed them out to each home we visited along with a gallon of water. There were other miscellaneous products like pasta, other forms of nonperishable canned meats, vegetables, and soups that were placed in bags that were designated for families that had five or more members. In addition, we gathered baby formula, diapers, toys, and medicine for families that had kids. Over 600 families were impacted by the students working on this project.

As with many service learning projects, I recognized that this endeavor necessitated documentation and that we needed to narrate our experiences. The students ultimately wrote not only about how the hurricane affected them, but what they learned by engaging in relief efforts in their own communities. This participation turned a positive volunteer experience into an educational exercise that fostered academic writing and critical thinking. Therefore, the purpose of the assignment was twofold: to encourage students to engage with and help victims of Hurricane Maria and for them to have an activity that would serve 
as the topic of their first essay written in English: an auto/biographical narrative, of the work they did in this project. This assignment opened so many doors for students to first write about their experiences, but to also talk and give advice about their involvement with the community. This natural disaster severely traumatized and affected everyday life for our student body. The implementation of the service learning project simultaneously helped students cope with their mental and physical stress, provided an opportunity to help their island in desperate times, and extended their learning space into the community.

The students participating in this project were primarily first-year students who scored on the lower tier of the College Board Exam and were placed in our introductory-level course track, "Basic English." The College Board is the standardized entrance exam that high school students take in order to apply to college in Puerto Rico. Students who score below the median are placed in Basic English. This course, although focused on grammar and language development, looked to involve relevant topics to promote critical thinking. After the hurricane, the course coordinators and faculty members decided to focus on issues concerning the Puerto Rican community after Hurricane María. In this particular assignment - knowing that the majority of my students had little writing experience - I specifically broke down the parts of the essay into individual writing days. The instructions required students to write a four-paragraph narrative on their experiences with our relief efforts. Some of the guiding questions and instructions were: Describe the devastation of the hurricane on the island. What was your role in the relief effort process? What were the reactions of the families you assisted? What did you learn from the process? And finally, what else should people do to assist these communities?
Students could write about any part of their involvement with the service learning assignment. The essay had a 300-word requirement, but that had to be modified almost immediately as students found themselves wanting to write about their roles in the project in a more extensive manner. UPRM students at the Basic English level tend to be more reserved and self-conscious about their writing in English. However, this autobiographical narrative of their relief effort experiences showed a willingness and excitement towards writing assignments that I had not seen before at the Basic English level. From a pedagogical standpoint, autobiographical assignments combined with service learning allowed students to delve at length into experiences that are relevant to their surroundings. The following are selected excerpts from student essays in chronological order from the hurricane to its aftermaths that serve as examples of the types of experiences the students wrote about and have been reprinted with permission.

Dana Abumoala Imagine everything you have had since you were born crumble in one minute. On September 20th of 2017, a category five hurricane with $185 \mathrm{mph}$ winds crossed Puerto Rico, devastating the island and severely affecting the economy. The electric power and the authority of water fell with the first gusts of winds.

Angel Zapata The process of recovery was extremely slow because the government didn't respond as fast as people hoped for, but thanks to many groups that decided to make the difference by helping communities in Puerto Rico be better and one of those particular groups were my classmates. Maria's impact gave us a new experience, especially to me, and united us to help each other.

Jesus Colon My participation and efforts for the initiative of the trips being directed to the first trip, with destination to Utuado. Those efforts became the foundation for the future trips. This trip was amazing, full of feelings, many experiences with the people that we met in the 
community of "Arenas" in Utuado. We met the young, old, man, woman, babies, disable ones. Seeing many houses without roof or houses that simply disappear.

Alexandra Alicea Volunteering for this trip opened my eyes to the veracity of the situation for those outside of the metropolis and I knew that after leaving the isolated communities behind, there was still work to be done and help to provide the perished.

Fiorella Vargas In moments like that, I feel hope in my island. We are passing through bad situation, but we are going to stand up stronger than ever. That was an experience full of different emotions I will never forget. We only need more people like my professor who motivates people to help, spread hope, and be heroes.

Service learning helped my students have a better sense of community, provided a relevant context for their academic writing, and worked to overcome hesitation with writing that I have previously observed in second language learners. Students learned that not only can they make a difference in times of crisis through their actions, but that they can also compose well thought out and structurally sound narratives about those experiences. Even though we talked about many hypothetical situations in the classroom to help Puerto Rico, these discussions will never compare to the feelings instigated by being actual agents of change and carrying out the plan. As pedagogues, it is important to discuss the significance of service learning and to consider incorporating it in our classes. Students need to feel a connection to their assignments, especially those assigned within courses taught in a second language. Service learning projects and the autobiographical narratives they often include, help to develop writing skills, but also a sense of leadership and compassion for the communities that they are assisting. It is always valuable for us to discuss new possibilities and take risks to ensure that our students develop their academic and interpersonal skills, especially those that focus on understanding the self within educational contexts.

\section{General Education}

On September 20, my homeland of Puerto Rico was struck by the strongest natural disaster it had experienced in over a hundred years, Hurricane María. The storm left the entire island without running water or electrical services and to this day (March 5) there are still people who have yet to have said services restored. Even last week, part of the island suffered from an electrical shutdown as many municipalities lost their recently restored power services. To say the island still needs work would be an understatement. However, many of us have found different ways to escape or overcome the traumatic and chaotic aftermath of Hurricane María.

Starting on September 18, just two days before María, I began carrying a notebook, and continued doing so in the months after the hurricane. In my notebook, I keep a diary consisting of auto/biographical poems, because poetry is the main genre I have been working in since I was a teenager. After five months of writing and close to ten notebooks filled with poetry about my life, on February 20, I decided to stop documenting my life after Hurricane María. Although, Puerto Rico is still recovering, I thought that keeping a diary where I would write multiple poems a day had become too much of a responsibility in a time where I needed to focus on other projects. On October 30 , one quarter of the way into this period of documentation, UPRM resumed classes and I thought my students, like me, might need to express their frustrations and overall stress regarding the post-hurricane situation. Below is an example of one of the many poems I wrote during the aftermath of Hurricane María: 


\author{
"September 30, 2017 11:12am": \\ "iaquí no hay pan, no hay!" \\ shouts an old man. \\ there's a lot to buy, \\ but it's mostly frozen food. \\ however, \\ that should tell you how essential bread is \\ to the puerto rican.
}

I believe in a Freirean-inspired classroom where students get to express themselves regarding the topics that are closest to them. I was teaching Intermediate-level English, a course in which the majority of the UPRM undergraduate students enroll and where I try to ensure that "[a]uthentic thinking, thinking that is concerned about reality, does not take place in ivory tower isolation, but only in communication" (FREIRE, 2005, p. 58). In light of my teaching philosophy, at the start of each semester, I typically introduce an activity in which the students write a poem about themselves and present it in front of the class as a means of introducing themselves in a creative manner and so that students can understand how important their voice and creativity is in the class. Therefore, I thought that resuming the semester with a creative activity, especially after such a chaotic episode, would not only help them express their feelings regarding the situation, but also find a way to record and reflect on their first hurricane experience while helping them further enhance their understanding of their environment and the time in which they were living.

I decided that this assignment would take the shape of crafting together a literary anthology of student work, Escaping María: Student Voices in Difficult Times. By creating an anthology and offering an opportunity to publish their work, I surmised that students would feel their work was being valued differently (both by the professor and other students, as well as by an external readership) and not positioned as just another assignment for class.
I did not want to obligate my students to participate in the book and, instead, left it open for them to decide if they wanted to contribute to the anthology. After living through such an experience, I could easily understand why they would not feel comfortable taking part in such a project. Some of them might have even been tired of talking about the subject. Thus, their participation in the anthology was optional. Many students, however, chose to participate under their own volition.

In a more typical class setting, students would be required to write poetry, but for this project I let those who wanted to participate use whatever genre or medium they chose, including visual narratives, as long as it could be documented in the book. In order to give them an idea of what genres they could use in the anthology, I delivered a presentation with the various forms of auto/biographical acts that could be used in the assignment. This PowerPoint presentation included a series of creative forms - as found in the "Author's Notes" section of Tony Medina's book The President Looks Like Me and Other Poems - that the students could use in order to express themselves and their personal experiences. The main options were poetic forms such as haikus, sonnets, blues poems, concrete poetry, and even raps. Among the other options provided were short stories, simple reflective essays, photography, drawings, and comix. By providing all these choices, the students saw a variety of options to express themselves and did not have to focus on one form of expression. Students were, therefore, able to practice their creative skills while also conveying their thoughts regarding such a different experience in their lives. While most students took a poetic approach to the anthology, others wrote short reflective essays. Below are examples of a few of the written works in Escaping María used with permissions of the authors: 
From “Ay María" by Gabriela Arroyo Calvo Could you tell me the cause of it? Puerto Rico is full of buena gente that like dancing their salsa and enjoying a good time while having a fría. I am just asking from you to not call any of your friends to come over to la Isla del Encanto because right now it is like an Isla del Espanto.

From "Escaping María" by Yampier Fernández Meléndez Hurricane María was a horrible event which devastated us, and nothing will change that. However, it taught me to appreciate every detail of my life and gave me the chance to take actions I normally never would. In a way, it even brought people closer and gave them the chance show many good qualities. In the end, what's important is that we can move on beyond our troubles.

From "Dear FEMA" by Gabriela A. Otero Andino Dear FEMA, If you ain't giving us our peace back, neither comfort to my family for us to see our town devastated or give me patience to do the long lines to get food or the strength to live without purified water, then go.

From "Thank You María" by John C. Tamayo Acosta

My condolences to everyone,

Who lost someone important,

I share your burden,

Now let's keep moving forward.

There is so much left to say but $\mathrm{i}$ don't think that I can,

Goodbye María, you have turned me into a man.

This pedagogical and creative project was done in an Intermediate-level English course focused on academic writing. However, I believe students need to find ways to express themselves in different ways. By giving them the opportunity to experiment with creative mediums, learners can find new forms of expression that, in turn, help them expand their minds beyond their fields of study whether they are majoring in the humanities or sciences, nursing, or engineering, etc. In addition, by giving them the chance to express themselves creatively and in a non-obligatory form, they were not given added stress in a moment in which they were likely affected in multiple ways by the storm and its aftermath.

Hurricane María was a terrible experience for the entire Puerto Rican community. I wanted to provide my students a platform from where they could express their feelings regarding the whole ordeal and what they lived through. That is how Escaping María came about. Having students document and publish their personal experiences is a way for young minds experience a public acknowledgement of their life stories and lives. For example, Fernández's reflection showed how important it was for him to look at the positive, while Otero demonstrated her anger towards FEMA and how it seemed their efforts failed to meet her expectations. With limited spaces in which to record frustration and hope, this anthology became a space of public voicing. The students put their words and experiences out there for anyone to see and, in this way, they can be viewed and witnessed. In a published anthology, students can visit their work, and that of their classmates, again and again (and be visited by others) in the future. The anthology also become a memorial for these students to look at the way they handled a very unique and difficult chapter in their lives, a space of voicing and witnessing.

In addition, this anthology served as a way for students to, as I state in many of my poetic works, "vomitar, desahogar, chonkiar" all of those experiences they had bottled up, but never had the opportunity to express. In his poem "in front of the class," my fellow poet, Bonafide Rojas, in his poem, "in front of the class," states the following " $i$ tell them to open their chests / and let whatever falls out / let it fall on the page" (pp. 53-55). This is what I wanted my students to do with this project and this is what I always implore them to do in my class whenever they have to write a paper. After completing this project, I continue to 
stand by a Freirean pedagogical philosophy in which our students have a personal voice in the classroom. In light of this approach, as the semester continued, I tried to find a balance between the mandated course syllabus and what was relevant to my students' post-Maria lived realities.

\section{Creative Writing}

"It became common to ask one another: Where were you during the hurricane?" observes one student, Alondra M. Perez Ramirez, in the beginning of her story about the most powerful tropical storm to hit Puerto Rico in over eighty years. This question is often brought up when a large group of people shares an experience - whether good or bad. If you ask someone where they were when the first man walked on the moon or when the Twin Towers collapsed you will get a very specific reply. I was at work. The phone rang. I could hardly recognize my husband's voice. "Check the news. Something horrible is happening."

This semester, in the two sections of creative writing I teach, students have the opportunity to write about the hurricane. They compose narratives based on their own experiences and they practice telling someone else's story. We begin by focussing on the power of specificity in writing. To do this, I introduce the ladder of abstraction, a concept conceived by linguist Samuel Hayakawa. Students practice moving down the ladder to create a concrete image from an abstract or general term. For example, fear moves down the ladder to the more concrete panic, which moves down to an actual image: I keep bailing the flood waters from my house, but no matter how fast I move, the water keeps coming! My heart thuds as I think: What will happen if I can't keep up?

In general, writers move up and down the ladder of abstraction. We want to talk about abstract concepts such as love, freedom, injustice, but it is generally agreed that we need specifics to make stories interesting. Author Jhumpa Lahiri notes that words, when vividly invoking "a person, place or situation," can stop time and can "affect us and alter us, as profoundly as real people and things do" ("My Life's Sentences"). In class, Lahiri's text reminds students that specificity is the tool that gives narrative the power to change a reader's (or writer's) ideas or perceptions.

This lesson is evident in the student writing that is produced by the follow-up exercise, which focuses on autobiography. Students write about their own experiences of a time before, during, or after the hurricane. They are encouraged to use present tense to bring immediacy to the scene, and I begin with a specific question: Where are you? One student, Joycemarie Vázquez Feliciano, writes about herself, her mother, and stepfather:

We're sitting in the living room with only a flashlight to break the darkness. We can kind of see what's happening outside through my glass door, but even worse are the sounds...l'm biting my nails, picking at my skin, talking nonsense, anything to avoid the haunting sounds. My mom's holding me close and my stepdad's holding her. She talks to me: "We're going to be okay. We're safe inside." What I didn't know then was that the rain and sounds of the wind were just the beginning, and the real nightmare would be living in a post-hurricane island with no electricity for months.

The students' replies span both experience and time. Kimberly A. Pagán Andujar describes her younger brother riding his bike the day before the hurricane. "I loved seeing him so happy, not knowing the hurricane was approaching." Her story concludes with her parents moving to the United States. She is homeless until, out of necessity, she moves to Mayagüez where she has "to start everything from scratch." The contrast between the hap- 
py domestic scene of a boy on his bike and her new reality is striking.

Not surprisingly, many of the hurricane narratives focus on events during the storm. Diego I. Vechioli Feliciano writes: "I see my roof flying. Below me is a pool created by the leaves stuck in the drain system. To my front, I see a tree planted by my grandfather that had fallen down and is on top of my sister's car. My mother is yelling to me and my father to come inside. She sounds both mad and terrified, but our house was a waterfall that we had to stop." The students' writing - though unedited - clearly reflects the lesson in specificity and is successful at producing vivid images. This is also demonstrated by Amarilis Yera López's story:

Cell phone screens show a hopeless "no service" message as we sit in the dark contemplating the possibility that our loved ones may be in danger and that the ones abroad may believe us dead...

Two weeks have passed since Hurricane Maria wreaked havoc upon the island. A joyous scream breaks the silence of the night as a woman down the street discovers a dial tone coming out of her home phone.

To conclude this exercise in autobiography, the students reflect on the experience of writing about the hurricane. Most agreed that it is a compelling topic and that, as Deigo says, "Everyone has a story to tell." Another student, Mario Seijo Garcia, remarks, "I felt like I was in the experience again and I thought this could impact the reader so when he or she read it, the person could feel the same as I did." His observation shows an understanding of the potential power of a vividly written scene.

Transitioning from autobiography to biography seems a natural progression when exploring how writing can promote student agency. To begin the next exercise, the students read a chapter from A Path Appears called "Philan- thropy by the Poor." As they read, they identify the different sources that were interviewed for the piece. They see that much of the content is based on quotes from other people. In addition, they see that - though set in Africa - the message of the writing may also be relevant here in Puerto Rico.

The chapter is about Bob Goff, an American lawyer, who founded a school in Uganda. Many of the students are orphans or were child soldiers, and they are all poor. Yet Goff has started a project where his students raise money to donate to underprivileged children in the United States. The idea of Ugandan kids giving to the affluent west seems surprising, but Goff wants to make sure "the students don't perceive themselves as charity cases" (KRISTOF and WUDUNN, 2014, p. 271).

Students in Puerto Rico see a connection to their situation on the island. It can sometimes be challenging not to succumb to a feeling of dependency in a place where the university is state funded, a majority of the students receive financial assistance, and where the whole island - especially post-hurricane - is depending on outside aid. The Ugandan students are inspiring because they have empowered themselves to help an unlikely beneficiary, but the story of Bob Goff and his students' work is in some ways even more inspiring. The power of their narrative once again illustrates to the students how storytelling can effect a change.

For the biographical exercise, the students interview each other and then write a short creative nonfiction piece. First, we discuss the responsibility of writing about other people's experiences and the need for accuracy, especially when quoting a source. This leads to a discussion of ethics and of a writer's power over the narrative of another person's story. They then get to select the subject of their interview and some students choose to, once again, focus on the hurricane. Angel A. Figueroa Dávila writes 
about how Alanis Nazario Mendez rescued an injured pigeon before the storm and cared for it for a month before it could fly again. Alanis's story illustrates a small act of kindness and concludes with her comments on the benevolent actions of others: "The most impressive thing she saw was the quick response of her neighbours to clear out the community's gate from trees that blocked it." Scenes like these perhaps serve to contrast the sense of social injustice some students express. In one interview Gabriel Pancheco Santa states, "I feel like our political system is so polarized that even in times of crisis we can't get our shit together." Gabriel is always thoughtful and articulate in class and, therefore, the anger in his statement resonates even more strongly. To wrap up the various exercises we have explored, I compile multiple excerpts from the student's autobiographical stories, which I read aloud in class. Students hear again and again how people took action - from small acts of kindness to larger relief efforts.

A project in which students write about the hurricane has multiple outcomes. The autobiographical exercise allows students to explore the power of conjuring a specific situation. The biographical exercise gives them insight into a writer's influence on someone else's narrative. All the hurricane narratives add to the collective history of this remarkable time in Puerto Rico. And, perhaps most importantly, these stories may allow students to regain a sense of control in a time when all illusion of personal power seems to have been literally blown away by the wind.

\section{Literature}

This past autumn, Hurricane María ravaged Puerto Rico, a "territory" of the United States. While the tempest and its destruction were terrifying, perhaps our true catastrophe was the way in which the United States federal government did not provide the necessary aid to the millions of US citizens who live in Puerto Rico. Classes at UPRM resumed on October 30 , despite the island still being largely without electricity, clean drinking water, internet, or medical services and supplies. Many of our students returned to campus with their homes and home-lives in shambles. Upon return, over 1000 students registered with our campus foodbank, Come Colegial, declaring that they were unable to procure food for themselves. Others joined a "couch surfing" group that helped those who no longer had a secure place to stay in Mayagüez to find a bed, a sofa, or a floor to sleep on.

When I restarted my undergraduate-level, Anglophone Caribbean literatures course after our approximately one-month hiatus, I did so recognizing the precarity of my students' situations. I was very cognizant of the lived trauma of the event: I too had stood in lines at banks only to be told that there was no money available, had seen the shelves of the cash-only grocery stores grow emptier and emptier, experienced the days with no gasoline to be had, and no clean drinking water to be found. The assignment that I discuss in this essay was, therefore, designed within the safe space of our learning community with the intent to reinforce students' individual agency in the face of a natural disaster that enacted a massive level of destruction and the inaction of a largely passive government that (inadvertently or purposefully) sent a clear message that some citizens are valued more than others. However, I also recognized that we needed to return to the work of our syllabus and find ways to bridge back from our lived experiences to the course materials. The purpose of this assignment, then, was twofold: to help students on a very human/e level while still bringing them back to the work of our course. 
With the dual objectives of facilitating student agency in a situation fraught with underpinnings of disempowerment and developing means to connect our witnessing perspectives to the assigned readings, I asked students to craft auto/biographical narratives as our first post-hurricane project. In this particular assignment - knowing that the majority of my students had been traumatized in some way by their hurricane experiences - I specifically employed brevity in the assignment instructions so as to allow for student interpretation of the project guidelines and not require testimony from my students, but, rather, offer the space for it, if the student needed or desired such a space. The instructions asked students to answer the following three questions: What have you survived during Hurricane Maria? What are you in the process of surviving in the aftermath of the hurricane? Do you see any connections between what you have survived and the texts we have read in class thus far?" Students were free to write as little or as much as they wanted to in their narratives, as long as they addressed my three questions in some way. I also dedicated the next class meeting to hurricane-related discussion and allowed anyone who wanted to do so time to read from their narratives or to discuss some point that writing their narratives had brought up. This public testimonial transaction, however, was in no way mandatory.

The responses were quite astounding for their length, depth, and specificity and solidified an inkling I had regarding the spaces available in our post-hurricane landscape for immediate testimony and witnessing. One observation that I made with my own hurricane experience was that we did not have time to share

6 At this point in the semester we had read "Fiesta, 1980" by Junot Díaz and "My Brother's Keeper" by Geoffrey Philp as well as several secondary and theoretical texts related to postcolonial theory and diaspora studies. our narratives, offer witness to the narratives of others, and, in turn, have our own narratives witnessed. Survival takes a great deal of time. When you are in the moment of procuring necessary supplies for your family, friends, neighbors, and even strangers, there is not enough time or energy left at the end of the day for narrative transactions. Of course, there was a continual sharing of micro-narratives throughout the aftermath of the deluge - snippets of where you have been, what supplies were available where, what had happened to you, etc. but no spaces had been created for the agency offered through the careful attention to fuller narratives. Situating the students' lived experiences in the classroom presented them with time to share their own life stories of survival and witness the testimonies of others, indicating the validity of their narrated lives as on par with required readings signifying the value of life narratives and the worth of the life in the narrative ${ }^{7}$

What I will focus on at this time are some of the ways in which students used their experiences with the hurricane to return to our assigned readings and what this example might mean for biographical methodologies in literature curricula. I offer below examples culled from some of the narratives my students shared with me. They have been reprinted with permission.

Andrea V. Valdés Valderrama The most relevant story to my experience with Hurricane María is Geoffrey Philp's “My Brother's Keeper." It provides an ideal ground upon which I can stand and see the relationship between the United States and Puerto Rico...Ricardo Rosello, the governor of Puerto Rico...embod[ies] [the character] Uncle George's nature, which was to "love anybody who gave him a drink" (435). [Roselló] sing[s] the President's praises, even as [the

7 I discuss in more depth the first part of these auto/ biographical narratives in, "Teaching Hurricane Maria: Disaster Pedagogy and the Ugly Auto/Biography" Pedagogy (19.1). 
President] laughs at the pain of Puerto Rico [...] where people are so desperate for aid, it seems okay to throw paper towels [...] at them.

José A. Fuentes Bonilla During Maria's aftermath, I could not stop thinking of "Fiesta, 1980," since I had been comparing myself to Yunior [the main character] this whole time...The promises that everything [in the United States] is better than here, no matter what, have stolen some of our Borincanos. We are living the same reality that Yunior was facing. Therefore, I compare myself to Yunior...now that we are living in a country destroyed by María.

Gustavo A. Hernandez Ortiz I relate with "Fiesta, $1980, "[. .$.$] because of Yunior and his family pov-$ erty [...] My family is not poor, but given the circumstances where we didn't have either water or power, it gives me that feeling. It was very difficult to get money from the banks and the little we could get was almost immediately gone.

Stephanie M. Fuentes Álvarez So, what's the personal situation I still find myself in? It's watching people or families have to leave for a better life - like in "Fiesta, 1980" and "My Brother's Keeper." It's relationships changing and being proud and happy [for those who leave], but still having that ache in my heart.

Joyce Acevedo While I was in Maine and Canada [after being evacuated], I felt like [the family] in "Fiesta, 1980." I was becoming homesick for my island and was rejecting everything in my surroundings [.] I was becoming sick with the thought of losing myself and my culture.

Yoshimarie Méndez Cancel I could [...] compare [the aftermath of the hurricane] with the theories discussed in class about migration, specifically when talking about the term "diaspora." This comparison can be made because many puertoricans left the island, but to other places where it is known that Puerto Rican culture is very much preserved and alive...I predict [that] [...] some of the people who have left because of the disaster will eventually return to Puerto Rico. This is called [return and] circular migration.

In our courses, we strive to promote critical thinking and the accompanying critical skills of reading, writing, speaking, and listening. If we understand these skills as an advancement of analytical reflection, empathetic understanding, and the promotion of a questioning mind that engages with and interrogates one's surroundings, the auto/biographical narrative within the classroom space holds the potential to craft bridges between our course syllabi and lived experiences for the benefit of demonstrating the relevance of our classroom lessons. Based upon and forged from my own experiences restarting a semester after a natural disaster, I posit that the pairing of the personal narrative with literary analysis has the potential to function as an anchoring mechanism for our students, one that links them to the class readings (canonical and otherwise) through pertinent and visible connections.

Of course, in this particular pedagogical unit, students in Puerto Rico were enrolled in a Caribbean literatures course at the time of a catastrophic natural disaster. The work of this course always invites students to reflect on their lived experiences based upon localized subjectivities - something that typically comes to the forefront in our classroom discussions. In this instance, however, students were specifically invited to share their hurricane memoirs as an aspect of the course. The purposeful incorporation of biographical methodologies in this literate course - as an assessed outof-class written assignment - led to more developed, complex, and nuanced articulations of the ways in which lived experiences met the analysis of assigned readings. While this type of commentary typically emerges in classroom discussions to some extent, the formality of the assignment overcame an impetus towards tangential comments in favor of carefully plotted and well-articulated interconnectivity, attributes of the assignments that stayed with us throughout the remained of the semester. While I am sincerely hopeful that no reader of 
this essay has the need to craft a disaster pedagogy of their own, I do pose that within and beyond the scope of crisis and trauma, there is a benefit to our students when we make the space for them to connect lived experience with critical reading practices.

\section{Linguistics}

The role of English in Puerto Rico is complex and layered. The imposition of English as the medium of instruction in schools as part of the US colonial project to Americanize Puerto Ricans pitted English against Spanish in the socio-cultural, political, and historical rhetoric of the country (Schmidt, 2014). At the same time, the global ideology of English as "the language of science," paired with a linking of English to mobility and fast capitalism, is exaggerated in still-colonial Puerto Rico (Carrol \& Mazak, 2017). As school children often resist their mandated English classes, they heartily consume English-medium popular culture, while at the same time facing the real possibility of their families migrating to the United States as Puerto Rico's crippled economy continues to drive its citizens to seek work elsewhere. Characteristic of colonialism, the relationship of Puerto Ricans to English is a constant push/ pull, with English's (often undelivered) promises of economic benefit and social mobility pulling at people living a scarred history of English as an acculturation tool of the colonizer.

Within this context, English language teaching as a profession is also contested. Though both English and Spanish are co-official languages in Puerto Rico, Spanish is decidedly the language of everyday life on most of the island. While English teachers are in great demand, speaking English "too well" or liking the language "too much" can also lead to social stigma (Perez-Casas, 2017). At UPRM, our Master of Arts in English Education program serves cur- rent and future English teachers who mostly come from undergraduate programs in Puerto Rico. These students face a constant negotiation of their relationship to both English and their own Puerto Rican identities. In order to encourage students to reflect on these relationships, members of a graduate-level course in literacy studies were asked to write literacy autobiographies, which are reported on here.

The goal of the course was to give students an introduction to the field of literacy studies, and then to read recent literature in the field, particularly as it intersects with newly developing theory around translanguaging. To this end, students read foundational pieces in literacy studies in order to understand the theoretical foundations of literacy practices and how this understanding applies to classrooms. During this foundational unit, called What is literacy?, students were asked to write a literacy autobiography.

The literacy autobiography assignment asked students to "write a narrative of about five pages which tells some part of your literacy autobiography." Students were asked specifically to "recount your experience with reading or writing, in any language or multiple languages," and to "show that you have reflected on your own literacy experiences." Students brought a draft to class, and each student read at least a paragraph from their draft aloud in class. This generated discussion and feedback from their classmates. Students then took this feedback and turned in a final draft of their literacy autobiographies a week later.

Many students wrote about their experiences as children becoming readers of English texts. Indicative of the push/pull of English in Puerto Rico, some reported that the interest that they developed in reading in English came as a surprise to their parents. Ashley Miranda Negrón writes: 
Since my early years, I had been exposed to Spanish language books and the idea of reading as a tremendously entertaining pastime. I vividly recall watching my mother read peacefully in the backyard hammock, and my constant interruptions begging for attention. Furthermore, I remember carrying my books everywhere, even during family vacations. During many of our trips, I was in charge of packing my small pink backpack which was always filled with books. However, as I started gaining independence and conscious knowledge of my literacy preferences, I developed a bias towards English language books. This caught both of my parents off guard, since neither of them had exposed me to the language. Moreover, by the time I was three years of age, on one of our family vacations my parents noticed I could interact in both Spanish and English fluently. However, they were quite puzzled since my interactions were solely limited to books and television screens.

Ashley's parents were both elementary school teachers, and so she had models of reading in her childhood. However, her parents read in Spanish, and little Ashley shocked them by preferring to read in English. This illustrates the role of English as a socially desired - but not culturally normalized - skill. Further, Ashley's parents didn't really expect her to learn English, despite being taught in school. Their shock partially came from her ability to learn English outside of school, through books and television. In other words, by her own agency and initiative, Ashley pursued English, and unexpected activity from her parents' perspective.

The agency of pursuing English learning outside of school was a common theme in the literacy autobiographies. In particular, students highlighted their pursuit of English text on screens. Mildred Vargas Astacio's mother wanted to enroll her in kindergarten early, seeing the young child's bright potential, but the school rules about cut-off age prevented her from doing so. Mildred went to Pre-K instead, but found it did not stimulate her developing mind:

Pre-K became boring, and I began developing more hobbies. From that moment on, I watched more T.V., read more books that my mother kept buying, and (finally) I got my Super Nintendo. With just 5 years, I became a gamer and I think this became a hobby that fed my ambition to learn more about languages in early years. The curious aspect of this is that I always programmed my videogame consoles in English and never in Spanish.

Young Edcel Cintrón recounted a similar experience:

Back when I was a five or six-year-old kid, I remember that something on the screen caught my attention. While playing the [video]game many times, I noticed the top part of the game had written text as well. The informational text displayed Mario's name. At the bottom of it, it showed your top score in the game. It also highlighted which world you were in, and how much time you had to pass the level you were currently playing. Thinking back at this experience, I would say this was my first experience with literacy as a social practice, because I was unconsciously reading gaming literacy and practicing how to use the mechanic to pass the game. If this also counted as my first literacy event, I would say it was my favorite first experience with literacy, since the interactions I had with video games guided me towards my interest in reading picture books during my early years in school.

Though we often (wrongly) think of reading as a passive activity, these excerpts show how the Puerto Rican graduate students in this class were agentive in their interactions with English text. Without much reported support from school-based English learning, they learned English because they were interested in the world it unlocked for them: the world of gaming, comic books, and novels. Among these accounts of English literacy development in a Spanish context, the story of Ashley stands out. Ashley writes: 
As the first-born daughter of two elementary school teachers, reading and writing in Spanish were skills I acquired early in life. However, it was in my grandparent's home where I first started acquiring the English language. As soon as I was one year old, every week day my grandparents would watch over me while my parents were at work. While my grandmother loved to tend her garden, my grandfather would spend his time watching numerous documentaries and programs in English. At the time, I was not aware my grandfather had hearing difficulties, hence why the subtitles were always enabled. As a result, every weekday from seven in the morning until three in the afternoon, while my parents were working, I had access to English language television shows and movies. Although I would watch multiple documentaries with my grandfather, my preferred channels were Disney Channel, Nickelodeon and Cartoon Network. This constant interaction led to unconscious learning of my second language. Therefore, when it came to texts in English, I was most familiar with subtitles on television screens.

Ashley, Mildred, and Edcel were smart, curious children who pursued English language literacy for their own purposes within a Spanish language context. That this context was Puerto Rico, with its long colonial history of English, further emphasizes these students' agency. They were finding English on their own terms and using it for their own purposes from a very young age.

As Puerto Rican students develop into Puerto Rican English teachers, they walk a carefully navigated path between appropriation of English and accusations of Americanization. Palo si bogas, palo si no bogas [a sink or swim situation]. English pulls at them with what they can do for students with promises of good jobs and social advancement. At the same time, to speak English too well pushes them to be called a gringito. But none of the students in the literacy studies class swallowed English whole in the way that the US intended when in 1899, Victor S. Clark, appointed president of the Puerto Rican Board of Education, famously said:

If the schools are made American, and teachers and pupils are inspired with the American spirit, and people of both races can be made to cooperate harmoniously in building up the schools, the island will become in its sympathies, views, and attitude toward life and toward government essentially American. The great mass of Puerto Ricans are as yet passive and plastic... Their ideals are in our hands to create and mold (DAVIS, 1899, p. 646, qtd. in MORRIS, 1995, p. 26).

Far from "passive and plastic," the use of literacy autobiographies in this graduate course showed the multiple ways in which these Puerto Rican graduate students and educators are agentive, creative, and intelligent in their pursuit of puertoriqueñidad on their terms. Their stories shine light on the lived realities of Puerto Ricans navigating their relationships with English within a contested colonial context.

\section{Assessment}

When we launched the Center for University Access I'd go to the public housing projects near the university to recruit students. In one of my first visits, I came upon an old man standing in a corner and told him what I was doing. He pointed me to a second-floor apartment in his building: "up there lives a very smart kid." I thanked him, went up, and knocked on the door, not knowing what to expect. A young kid opened the door and I explained what I was there for. He was a senior in high school. I asked him if he had taken the college entrance examination test and he answered affirmatively, but soberly. The results had arrived weeks before, but the envelope laid unopened on a corner table. I asked him if he wouldn't mind opening it and he agreed. I couldn't believe it! This kid had earned a nearly perfect score in math, only three wrong answers. "What are your plans?" I asked him. "Well, I know I'm not going to fall for drug dealing; I made that decision a long time ago. I just 
got a job working 15 hours per week at a nearby Church's, I'm going to save money to buy a used car so that I can get licensed to operate a public transportation car." (David González, CUA founding member)

In his seminal essay about oral history in Puerto Rico, Antonio Díaz Royo persuasively argues that in the Puerto Rican colonial context, oral history is a praxis that spurs the knowledge and transformation of our society and advances democratic prospects. Thus, in our context, oral history should be regarded not just as a research technique, but as a way of channeling the search for truth that "shakes traditional social science and breaks the interpretive confines that it represents in the colony." The oral historian adds, "En un mundo colonial, estructuralmente concebido para otros, poder evidenciar la continua resolución del proceso histórico de las relaciones sociales es un acto descolonizador pues la colonia solo triunfa culturalmente con la erradicación de la conciencia histórica."

More than thirty years after Díaz Royo's plea for decolonizing oral history projects, and despite the far-reaching influence of classics like Sidney Mintz's Worker in the Cane and César Andreu Iglesias's Memorias de Bernardo Vega, oral history research continues to be an exiguous research praxis in Puerto Rico. At the present juncture, when the imposition of a draconian Financial Oversight and Management Board by the United States Congress threatens to deplete the Puerto Rican archipelago's resources for the provision of essential services - such as health and education - to its dwindling and aging population in order to repay a national debt whose legality is questionable, oral history emerges as a compelling strategy to document life stories and individual and collective struggles forged against the grain of exclusionary meta-narratives of Puerto Rico's current plight.
The ongoing project discussed in this essay - undertaken with my collaborator, Adriana E. Lebrón Larrache - is an effort to chronicle the struggles for access to higher education in Puerto Rico and the role that the University of Puerto Rico, the only public institution of higher learning in the country, has played as a social equalizer since its foundation in 1903. According to the Organic Law of the University of Puerto Rico, one of the institution's objectives is to: Desarrollar a plenitud la riqueza intelectual y espiritual latente en nuestro pueblo, a fin de que los valores de la inteligencia y del espíritu de las personalidades excepcionales que surgen de todos sus sectores sociales, especialmente los menos favorecidos en recursos económicos, puedan ponerse al servicio de la sociedad puertorriqueña. ${ }^{8}$

One of the many valuable initiatives spearheaded by UPR actors committed to pursuing the democratization of higher education in Puerto Rico is the Center for University Access (CUA) of UPRM. Originally established in Spring 2007 by two UPRM professors supported by an institutional grant and accompanied by a dozen UPRM student volunteers, the CUA became a formal social justice in education project at UPRM in 2008, with funding from the Fundación Francisco Carvajal and other external and institutional sources. Over the past decade, the Center has risen as an effective initiative dedicated to conducting academic research and outreach activities that address the connection between socioeconomic inequality and educational access, and to increasing the proportion of socioeconomically disadvantaged students that apply, are admitted to, and successfully graduate from public higher education in Puerto Rico. It is, predominantly and purposefully, a UPRM student-run operation whose paid staff includes a large number of former participants in the CUA's outreach pro-

8 Citation to Law 1 of January 20, 1966, as amended. 
gram. Faculty coordinators spearhead research projects, oversee the Center's administration, and collaborate with student and professional staff. Services provided include academic tutoring, individualized mentoring, advocacy, professional psychosocial support, family and school visits, needs-based workshops, educational summer camps, and college admission test preparation to students who reside in subsidized housing projects in the Mayagüez area and are enrolled in public middle- and highschools, or those who have been admitted to an institution of higher education.

This concerted set of interventions is not only attuned to the stated UPR objectives, but also informed by research. A study conducted by CUA founding members Rima Brusi and David González in 2007 revealed that only 0.3 percent of the students admitted into UPRM from 1990 to 2006 came from any of the eighteen subsidized housing projects in the municipality of Mayagüez. ${ }^{9}$ Moreover, former CUA researcher Sandra Dika concluded in a 2010 study that "evidence from UPRM suggests that the attrition rates for low-income students are twice as high as their higher income peers" and that "parent income and education level play a key role in predicting retention."10

Early intervention has been the CUA's response to this state of affairs. In an educational, cultural and social context that "teaches" low-income youth from caseríos (subsidized housing projects) located just a few miles from the UPRM campus that college is not an option for them, the CUA pursues the dual objective of strengthening their academic skills and performance and fomenting their college

9 Brusi Gil de la Madrid, R. "Si te dejas llevar..." Universidad, Geografía y Desigualdad. Primer Cuaderno de Trabajo, Proyecto Carvajal para la Democratización del Conocimiento, 2009.

10 Dika, S. Student Persistence: Socioeconomic Factors Related to Student Peristence at the University of Puerto Rico. Third Working Paper, Proyecto Carvajal para la Democratización del Conocimiento, 2010. aspirations. This concerted effort has rendered transformative results. In the first five years of the project, ninety-five percent of its participants remained in school and completed their high school education. National school retention rates for the same period were significantly lower at fifty-five percent.11 Moreover, higher education admission rates of CUA school-level participants are exceptionally high: over the past three years, 100 percent of CUA participants who have applied to postsecondary education programs upon graduation have been admitted, most of them at UPRM. CUA enrollment has remained consistently high in the past four semesters at an average of $100 \mathrm{mid}$ dle- and high-school students and forty-five college students per semester. The success of this social justice in education model, however, cannot be encapsulated in numerical figures.

At a historical juncture when a nonelected colonial Junta is demanding budgetary reductions tantamount to the effacement of the University of Puerto Rico as the principal institution of higher education in the country and the region and equally drastic cutbacks to the budget of the Department of Education, it is imperative to add nuance and depth to the evolving educational debates by appealing to the memories and life stories of those who are spoken for and, thus, silenced in colonial fiscal policy rhetoric.

With this context in mind, Adriana Lebrón, a graduate student in the Master of Arts in English Education program at UPRM, undertook, under my guidance, an oral history project about the CUA in August 2017. Its design and implementation were justifiably delayed due to the devastating consequences of hurricanes Irma and María, which hit Puerto Rico in September

11 Rolón Collazo, L. and González Barreto, D. Poder es querer: Pobreza y acceso universitario público en Puerto Rico según el caso de la UPRM. Octavo Cuaderno de Trabajo, Proyecto Carvajal para la Democratización del Conocimiento, 2013. 
and thereafter exposed the historic neglect of Puerto Rico's large and growing impoverished population. Despite these challenges, the oral history project is underway and extensive oral history interviews were conducted between January and March 2018. The project's four narrators include: one UPRM faculty member who was part of the CUA's founding members and original team of researchers; one UPRM faculty member who coordinated the CUA for three years and eventually established and coordinated the Colectivo Universitario para el Acceso, a CUA-inspired multi-campus initiative that included six of the eleven UPR campuses; a former CUA participant who partook in the project from middle-school through college, worked as a CUA tutor and mentor, and completed his degree in Physics from UPRM; and a current CUA student staff member who partook in the project during her middle- and high-school years.

Full transcripts of the oral history interviews are not yet available but, as the epigraph and the following excerpt demonstrate, the oral histories recorded stand as testimonies of (if not against) the systemic colonial dynamics that eclipse the horizon of possibilities for socio-economically disadvantaged youth. Moreover, they comment on the dire conditions of underpaid teachers, underfunded schools, and under-supported educational research in contemporary Puerto Rico - a state of affairs that is likely to worsen in years to come, under the austerity measures imposed by the Financial Oversight and Management Board:

Cuando estuve en la Roosevelt, en elemental, no fue tan malo, pero cuando entré a "la piloto", en intermedia, ya la cuestión cambió drásticamente. Le decían "la piloto" porque ahí tú vuelas, como dicen, por debajo del radar; tú podías ir a la escuela, no hacer nada, y graduarte como quiera, sin esforzarte. La escuela está básicamente dentro del residencial. Cuando los residenciales estaban en guerra, los estudiantes también estaban en guerra dentro de la escuela y eso eran peleas todos los días. Los maestros ya estaban hastiados de los estudiantes, so era más fácil para ellos decir "dale, vete, gradúate, no importa; si quieres prestar atención, pues presta atención, sino, pues, chávate" que estar bregando con ellos. Ese era el estilo donde de mi educación.

(former CUA participant and student staff member, UPRM alumnus)

Personal narratives, the indubitable product of selective and creative memory work, break silences but also weave connections, collaborations, and confabulations. David González - one of the oral history project narrators, who is a founding CUA member, a UPRM alumnus and a successful UPRM professor was once a marginalized barrio public school student. This excerpt from his recent interview contextualizes the conditions that mitigate against access to higher education recalled by the narrator cited above and also underscores the need to engage in transformative research and actions that contribute to revoicing collective grievances, and organizing to redress them, especially in the current juncture:

Cuando acepté trabajar en la Oficina de Investigación Institucional y Planificación del RUM en 2006 yo mantenía un foldercito que se llamaba "comunidad y residenciales". Empecé a guardar datos y me empecé a dar cuenta de cosas descomunales: que no entraba nadie, que se graduaban pocos, que de la escuela vocacional no entraba nadie, que de mi barrio no venía nadie, que de los barrios que yo conocía no venía nadie, que de los residenciales no venía nadie. Siempre tenía la inquietud de saber: de la gente del barrio, ¿cuantos llegaban para acá?; de comunidades con necesidades socioeconómicas, ¿cuántos?, porque de hay es que yo venía [...] Por eso, para mí, era importante que existiera el CUA. 


\section{References}

ASTIN, Alexander W. et al. How service learning affects students. Higher Education, Paper 144, 2000.

BRUSI GIL DE LA MADRID, R. "Si te dejas llevar..." Universidad, Geografía y Desigualdad. Primer Cuaderno de Trabajo, Proyecto Carvajal para la Democratización del Conocimiento, 2009.

CARROLL, K. S.; MAZAK, C. M. Language policy in Puerto Rico's higher education: opening the door for translanguaging practices. Anthropology \& Education Quarterly, v. 48, Issue 1, p. 4-22, 2017.

DíAZ ROYO, A. T. La historia oral en Puerto Rico: reflexiones metodológicas. Secuencia: Revista de historia y ciencias sociales, v. 4, p. 123-133, 1986.

DIKA, S. Student Persistence: Socioeconomic Factors Related to Student Peristence at the University of Puerto Rico. Third Working Paper, Proyecto Carvajal para la Democratización del Conocimiento, 2010.

ERASMUS, M. A. Embedding service learning in South African higher education through good practices and quality management. In: MOORE, Mary; LIN, Phylis Lan. (Eds.). Service-learning in higher education: paradigms and challenges. Indianapolis: University of Indianapolis Press, 2009. p. 43-63.

FREIRE, Paulo. Pedagogy of the oppressed. Tradução de Mayra Bergman Ramos. New York City: The Continuum International Publishing Group Inc., 2000.
KRISTOF, Nicholas D., WUDUNN, Sheryl. A path appears: transforming lives, creating opportunity. New York City: Alfred A. Knopf, 2014.

LAHIRI, Jhumpa. My Life's Sentences. The Opinionator Blog at The New York Times, 17 mar. 2012, opinionator.blogs.nytimes.com/2012/03/17/ my-lifes-sentences/. Accessed: 22 mar. 2018.

MORRIS, N. Puerto Rico: Culture, politics, and identity. Westport: Praeger Publishers, 1995.

PÉREZ-CASAS, M. Codeswitching and identity among Island Puerto Rican bilinguals. In: GUZZARDO, R.; MAZAK, C.; PARAFITA, COUTO, M. (Eds.). Spanish-English codeswitching in the Caribbean and the U.S. Amsterdam: John Benjamins, 2017. p 37-60.

ROJAS, Bonafide. In front of the class. In: ROJAS, Bonafide. When the city sleeps. New York City: Grand Concourse Press, 2012. p. 115-17.

ROLÓN COLLAZO, L.; GONZÁLEZ BARRETO, D. Poder es querer: Pobreza y acceso universitario público en Puerto Rico según el caso de la UPRM. Octavo Cuaderno de Trabajo, Proyecto Carvajal para la Democratización del Conocimiento, 2013.

SCHMIDT, J. The Politics of English in Puerto Rico's Public Schools. Boulder: First Forum Press, 2014. Aprovado em: 30.07 .2018

Ricia Anne Chansky is Professor of literature at the University of Puerto Rico at Mayagüez. She is coeditor of the scholarly journal, $a / b$ : Auto/Biography Studies, and editor of the new Routledge Auto/Biography Studies book series. She coedited The Routledge Auto/Biography Studies Reader and edited two volumes, Auto/Biography in the Americas: Relational Lives and Auto/Biography across the Americas: Transnational Themes in Life Writing. She has published on auto/ biographical narratives in relation to diaspora and pedagogy, diaspora and gendered identity constructions, and visual culture and feminist rhetorics. She has forthcoming publications on disaster pedagogy, reading auto/biographical narratives in times of crisis, gendered identities in the Americas, and contested US national identities.

e-mail: ricia.chansky@upr.edu

Department of English, University of Puerto Rico at Mayagüez, Campus Box 9265, Chardón Hall Room 323, Mayagüez, Puerto Rico 00681. 787-832-4040 x. 3064

Edward Contreras Santiago is an Instructor at the University of Puerto Rico at Mayagüez and a Ph.D. candidate at the University of South Florida in the field of Second Language Acquisition with Instructional Technology. His current line of research focuses on translanguaging practices and international Graduate Teaching Assistants' language practices at the student and instructor level. In addition, he is the co-coordinator, with Dr. Rosita Rivera, of the Institute for the Teaching and Study of Language and Assessment (ITSLA), where he also serves as an instructor. Some of his research 
interests include: Second Language Acquisition, Computer Mediated Communication (CMC) and Language Learning, Development of ESL, Test Preparation courses, and Service Learning. e-mail: edward.contreras@upr.edu

Department of English, University of Puerto Rico at Mayagüez, Campus Box 9265, Chardón Hall Room 323, Mayagüez, Puerto Rico 00681. 787-832-4040 x. 3064

Fernando Correa González is a Master of Arts in English Education student and Graduate Teaching Assistant at the University of Puerto Rico at Mayagüez. His thesis focuses on Afro-Boricua poetry. He has been an instructor and tutor for four years. In addition to education, Correa González also works as a poet, filmmaker, and cultural organizer who has self-published over ten poetry books and collaborated in a variety of short film projects. After graduating from UPRM, he wishes to focus on his artistic projects while working as an educator. e-mail: fernado.correa1@upr.edu

Department of English, University of Puerto Rico at Mayagüez, Campus Box 9265, Chardón Hall Room 323, Mayagüez, Puerto Rico 00681. 787-832-4040 x. 3064

Marci Denesiuk holds an MA in Creative Writing and English Literature from Concordia University in Montreal, Canada. Her published work has won awards and includes a book of short stories, The Far Away Home, as well as fiction and nonfiction contributions to anthologies and magazines. She currently teaches literature and creative writing at the University of Puerto Rico in Mayagüez. e-mail: marci.denesiuk@gmail.com

Department of English, University of Puerto Rico at Mayagüez, Campus Box 9265, Chardón Hall Room 323, Mayagüez, Puerto Rico 00681. 787-832-4040 x. 3064

Jocelyn Géliga Vargas received a B.A. in Communication from the University of Puerto Rico- Río Piedras (1989), an M.S. in Broadcast Journalism from Boston University (1991), and a Ph.D. in Communication from University of Massachusetts-Amherst (1999). Her recent publications in books and academic journals address oral history and life writing, Afro-Puerto Rican and Afro-diasporic identities, Caribbean cinema, and collaborative/participatory research methodologies. Since 2006, she has been coordinating an Afro-Puerto Rican oral history project in western Puerto Rico, originally funded by the Latin American Studies Association (LASA) and the Faculty of Arts \& Sciences at UPRM. She is currently the Graduate Writing Facilitator's Coordinator at the Graduate Research and Innovation Center at UPRM and the cocoordinator of the CUA.

e-mail: jocelyna.geliga@upr.edu

Department of English, University of Puerto Rico at Mayagüez, Campus Box 9265, Chardón Hall Room 323, Mayagüez, Puerto Rico 00681. 787-832-4040 x. 3064

Catherine Mazak is Co-director of CeIBA and Professor of English at the University of Puerto Rico, Mayagüez. She received her PhD in Critical Studies in the Teaching of English from Michigan State University and her M.A. in TESOL from the University of Arizona. She is the coeditor of two books, Translanguaging in Higher Education: Beyond Monolingual Ideologies and Spanish-English Codeswitching in the Caribbean and the US. She studies bilingualism in higher education using ethnographic and other qualitative research methods, and researches practices of translanguaging. e-mail: catherine.mazak@upr.edu

Department of English, University of Puerto Rico at Mayagüez, Campus Box 9265, Chardón Hall Room 323, Mayagüez, Puerto Rico 00681. 787-832-4040 x. 3064 